\title{
COVID-19 and its Impact on Small and Medium Enterprises: Evidence from Malaysia
}

\author{
Hanafiah Hasin, Anita Jamil, Yang Chik Johari, Eley Suzana Kasim
}

To Link this Article: http://dx.doi.org/10.6007/IJARAFMS/v11-i3/11437 DOI:10.6007/IJARAFMS /v11-i3/11437

Received: 29 July 2021, Revised: 24 August 2021, Accepted: 17 September 2021

Published Online: 26 September 2021

In-Text Citation: (Hasin et al., 2021)

To Cite this Article: Hasin, H., Jamil, A., Johari, Y. C., \& Kasim, E. S. (2021). COVID-19 and its Impact on Small and Medium Enterprises: Evidence from Malaysia. International Journal of Academic Research in Accounting Finance and Management Sciences, 11(11), 719-739.

\section{Copyright: @ 2021 The Author(s)}

Published by Human Resource Management Academic Research Society (www.hrmars.com)

This article is published under the Creative Commons Attribution (CC BY 4.0) license. Anyone may reproduce, distribute, translate and create derivative works of this article (for both commercial and non-commercial purposes), subject to full attribution to the original publication and authors. The full terms of this license may be seen at: http://creativecommons.org/licences/by/4.0/legalcode

Vol. 11, No. 3, 2021, Pg. 719 - 739

Full Terms \& Conditions of access and use can be found at http://hrmars.com/index.php/pages/detail/publication-ethics 


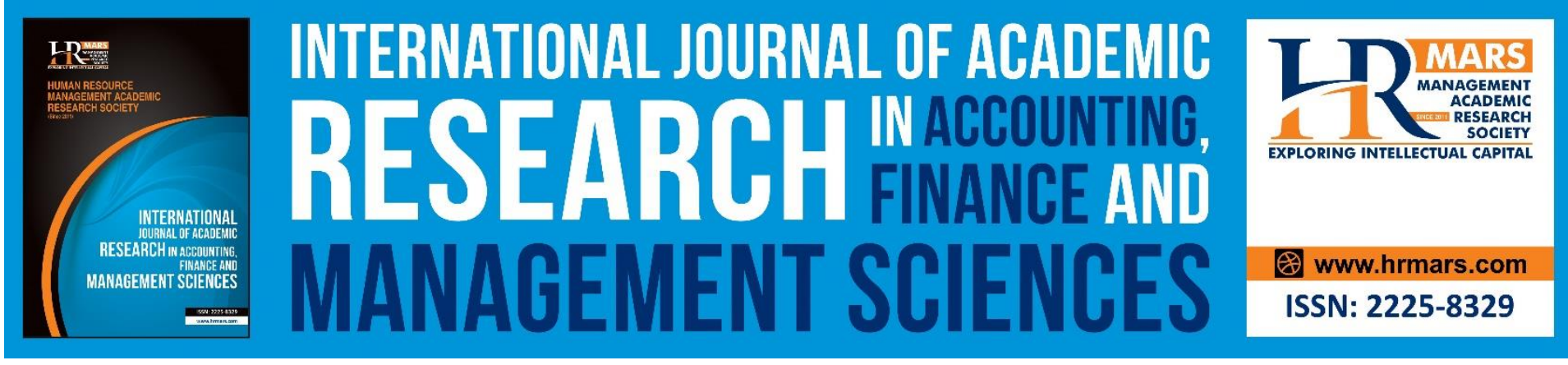

\title{
COVID-19 and its Impact on Small and Medium Enterprises: Evidence from Malaysia
}

\author{
Hanafiah Hasin ${ }^{1,2}$, Anita Jamil ${ }^{1}$, Yang Chik Johari ${ }^{1}$, Eley \\ Suzana Kasim² \\ ${ }^{1}$ Faculty of Accountancy, Universiti Teknologi MARA, Cawangan Melaka, Kampus Alor \\ Gajah, ${ }^{2}$ Accounting Research Institute, Shah Alam, Selangor
}

\begin{abstract}
The COVID-19 pandemic has inflicted nations with enormous impact, socially and economically. This study seeks to examine the impact of COVID-19 on SMEs in Malaysia. The data was collected from a questionnaire-based survey and interviews conducted in July and early August 2020. The results of this study focused on the background of the SMEs, the impact on SMEs during Covid 19 crisis, particularly on the use of online distribution channel to sustain their business, and the economic stimulus package provided by the government to the SMEs. Findings showed that the severity of COVID-19 impact on SMEs in Malaysia differs according to the nature and size of the business. Among the impacts noted in this study are disruption in the business operation, reduction in both the supply and demand of the products, low production, financial instability, and the shift to the digital distribution channel. Moreover, this study indicated that government intervention plays a significant role in facilitating the SMEs to sustain their business in the industry.
\end{abstract}

Keywords: SMEs, Malaysia, COVID-19, Economy, Impact, Movement Control Order.

\section{Introduction}

The COVID-19 pandemic is a worldwide outbreak that has inflicted nations with enormous impact, socially and economically. Within the South-East Asian region, Malaysia was the fourth-largest economy that has managed to do well for the last few years before the pandemic. However, with the pandemic, COVID-19 had reversed national development tremendously to $-6 \%$ in 2020. During early 2020, the International Monetary Fund (IMF) predicted that economic recovery would take time and that a quick turnaround would occur in October 2020, leading to a growth rate of $7.8 \%$ in 2021 and later stabilising at $6 \%$ in 2022, subject to the global economic rebound after the pandemic.

Additionally, based on the data from World Economic Outlook updated in April 2021 (Figure 1), the real GDP growth for Malaysia was projected at $6.5 \%$ in 2021 and will reduce to $6 \%$ in 2022. A similar trend is anticipated for the GDP at the global level and advanced and developing economies (Figure 1). For instance, in 2021, the GDP of other emerging market and developing economies countries are expected to be $6.7 \%$ before dropping to only $5 \%$ in 
MANAGEMENT SCIENCES

Vol. 11, No. 3, 2021, E-ISSN: 2225-8329 @ 2021 HRMARS

2022 (IMF, 2021). Nevertheless, IMF predicts that Malaysia will outperform the global and even the advanced economies GDP in 2022.

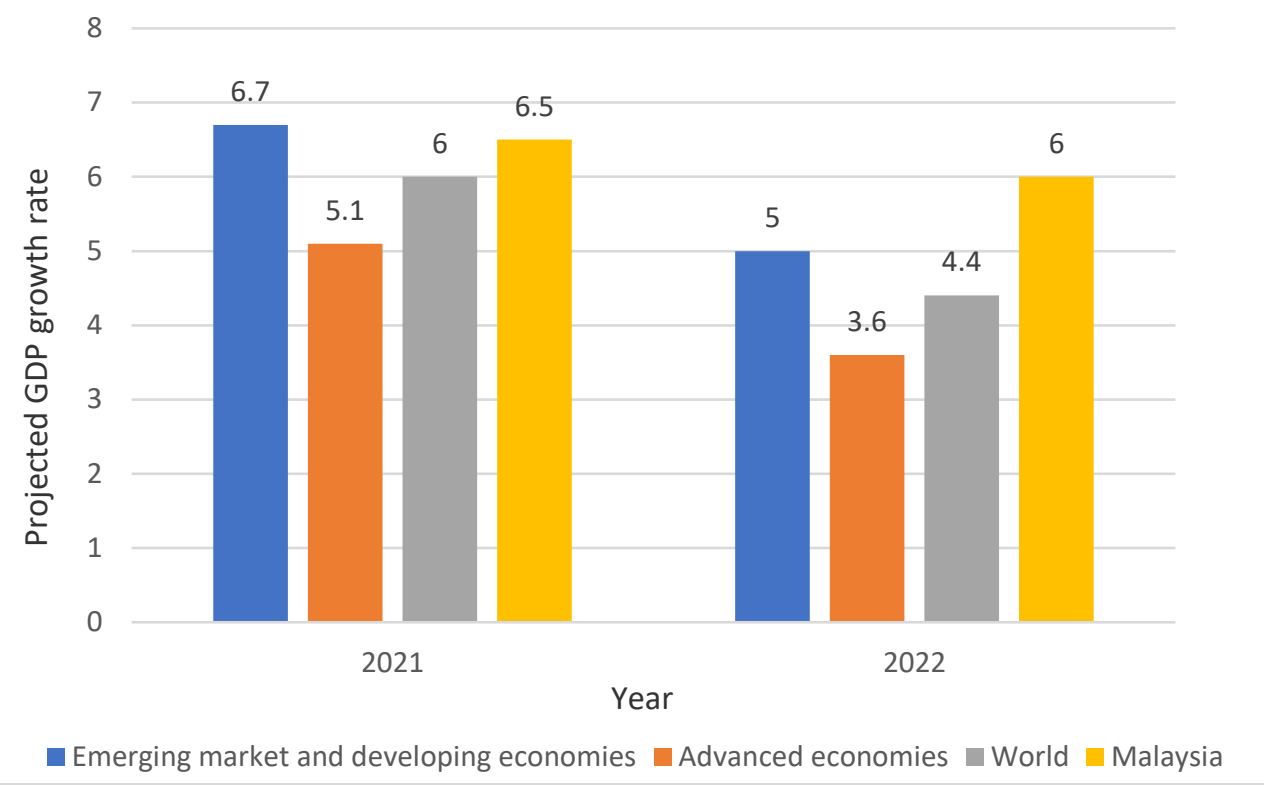

Figure 1

Projected GDP post COVID-19

Adapted from: World Economic Outlook April 2021, IMF (2021)

The economic downturn has a significant adverse impact on the business community, regardless of their size (OECD, 2020). However, while large businesses may have higher capabilities to stay resilient in the COVID-19 crisis, smaller businesses may have been at a disadvantage (McKinsey, 2020; Djalante et al., 2020; Sansa, 2020; Tashiro and Shaw, 2020; Kokudo \& Sugiyama, 2020; Ruiz Estrada et al., 2020; Smith \& Judd, 2020; Buffington et al., 2020). According to findings from many surveys conducted in several countries, between $25 \%$ and $36 \%$ of small firms could close permanently because of the disruption in the first four months of the pandemic (McKinsey, 2020). In Malaysia, the Small and Medium Enterprises (SMEs) were most badly hurt by the pandemic, where more than 32,000 had to close operations (FMT, 2020).

Table 1

Number of SMEs facing closure

\begin{tabular}{|c|c|}
\hline Indicator & Item \\
\hline $\begin{array}{l}1^{\text {st }} \text { phase MCO } \\
\text { March } 18 \text { - June 9, } \\
2020\end{array}$ & 9,675 \\
\hline $\begin{array}{l}\text { Recovery MCO phase } \\
\text { June } 10 \text { to Sep }\end{array}$ & 22,794 \\
\hline Total & 30,269 \\
\hline
\end{tabular}


MANAGEMENT SCIENCES

Vol. 11, No. 3, 2021, E-ISSN: 2225-8329 @ 2021 HRMARS

The economic wellbeing of SMEs has become a major focus of many countries (Sneader \& Singhal, 2020) in responding to COVID-19, including Malaysia. Failure to address the recovery of the SMEs will have a major impact on the quality of life of vulnerable segments within the society, especially the lower-income earners who operate small and medium businesses (Gourinchas et al., 2020). It could affect the nation's achievement of Sustainable Development Goals (SDGs) such as no poverty (SDG1) and the national aspiration of Shared Prosperity Vision 2030. Given this concern, the Government of Malaysia announced several stimulus packages (Figure 2) to support the SMEs financially.

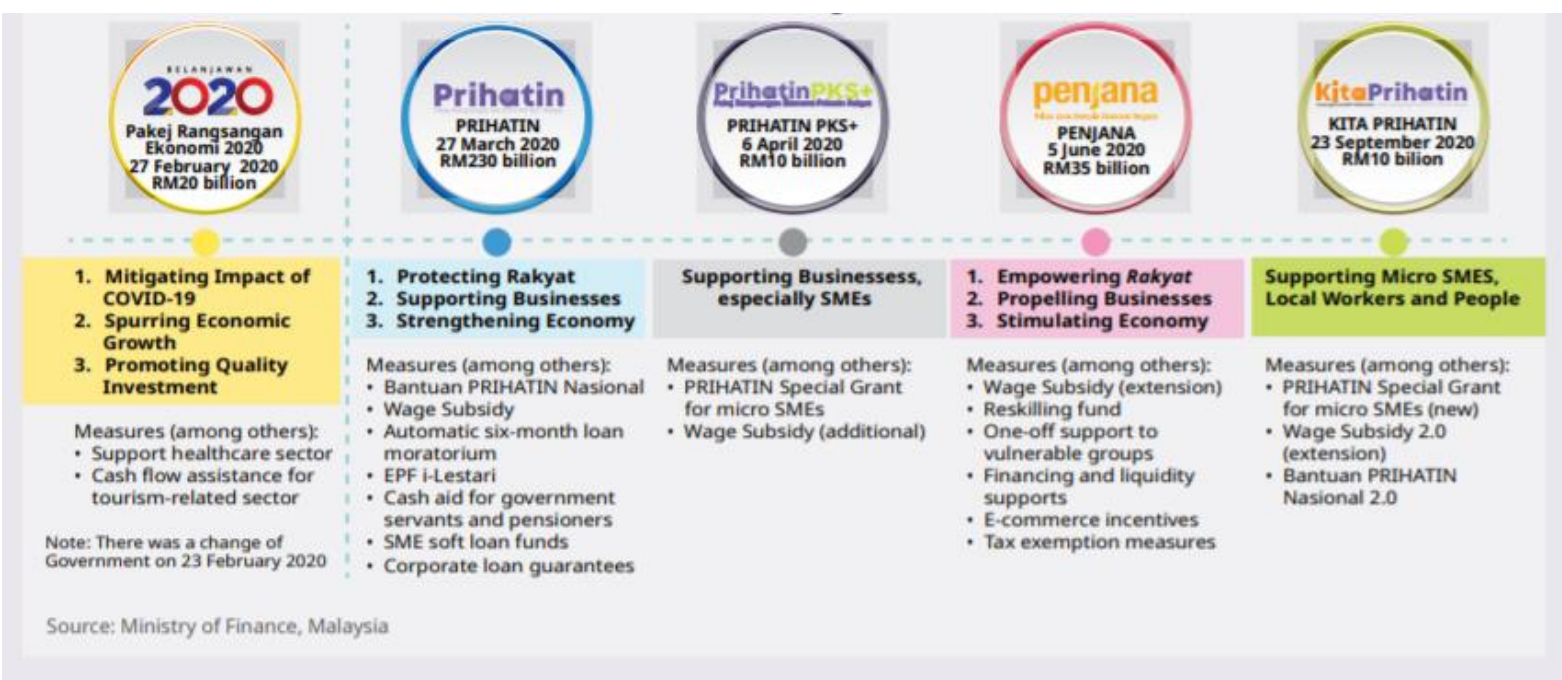

Figure 2: Economic Stimulus Package for COVID-19 pandemic Source: Ministry of Finance Malaysia

As shown in Figure 2, the stimulus package started with Pakej Rangsangan Ekonomi 2020, which was introduced on 27 February 2020. On March 27, 2020, the government unveiled a new programme of RM230 billion, called the Prihatin Rakyat Economic Stimulus Package (PRIHATIN). PRIHATIN provided cash transfers to compensate for income loss and wage subsidies to encourage firms to keep employees. Subsequently, an additional RM10 billion was distributed through the PRIHATIN PLUS package, particularly to help the SMEs. This support was later strengthened by the RM35 billion Pelan Jana Semula Ekonomi Negara (PENJANA) programme, inaugurated on June 5, 2020. The key objective of PENJANA was to restart the economy by offering incentives to people and businesses to resume their operations in the midst of the new normal. Subsequently, On September 23, 2020, an additional stimulus programme of RM10 billion was announced to reduce people's burdens and keep businesses afloat. This package was known as the PRIHATIN Supplementary Initiative Package (KITA PRIHATIN). KITA PRIHATIN was targeted to benefit the micro-SMEs. These stimulus packages highlighted the government's key role in assisting SMEs to sustain their businesses.

Despite the availability of financial support for SMEs, the effectiveness of such government initiatives may be hampered due to the lack of information on the predicament caused by the pandemic on the SMEs. This raises three important questions: (1) In what ways are the SMEs impacted by COVID-19? (2) What are the challenges facing the SMEs in responding to the pandemic? (3) How do the SMEs distribute their products amid COVID-19? Thus, this study seeks to examine the impact of COVID-19 on SMEs in various industries in Malaysia, 
MANAGEMENT SCIENCES

Vol. 11, No. 3, 2021, E-ISSN: 2225-8329 @ 2021 HRMARS

identify the most selected stimulus package received by the SMEs, and examine the distribution channel used by SMEs to sustain in the industry.

In more specific, the current study focused on the sustainability strategy used during the COVID-19 pandemic. The study looks at techniques such as digital distribution channels to face threats created by the COVID-19 pandemic. It is also contributing to the growing literature on SME's strategy used during the crisis. It provides additional insights for SME managers and policymakers about the importance of government support in strengthening the financial position of SMEs during the crisis. Findings from this study will provide a useful guide for the policymakers in strategising to facilitate the SMEs, especially in times of crisis.

\section{Literature Review COVID-19 Pandemic}

In December 2019, the first COVID-19 epidemic in Wuhan, China, led to mass death and spread to almost every region of the country (Akanni and Gabriel, 2020; Carlos et al., 2020; Riou \& Althaus, 2020; Wang et al., 2020, Li et al., 2020). However, the pandemic was well controlled by China's actions through steps that have been effectively implemented to prevent the spread of the virus in China. Similar interventions were suggested to be applied to other countries in the world. Despite China's success, it remains questionable whether similar actions will work with other countries (Kupferschmidt \& Cohen, 2020). As of 2020, mainland China was reported to have only a few newly diagnosed cases every day (Zu et al., 2020).

In Malaysia, COVID-19 was first discovered on the 25th of January, with cases linked to previously infected individuals who had stayed in Singapore with travellers returning to China (Ting, 2020). Several countries have used a combination of containment and prevention to deal with COVID-19's health and economic crisis (Bedford et al., 2020). The government of Malaysia, like other countries, take important measures to prevent virus transmission to the population. On 18 March 2020, Malaysia's Prime Minister announced a national lockdown whereby a movement restriction was imposed on every citizen. These include restricting non-essential businesses and installations such as holding public meetings, education centres, religious services, sports activities, social and cultural events. Only essential facilities can be operated for two weeks, such as sewage, electricity services, postal services, transportations, drainage, gas and fuel services, gasoline, lubricants, radio transmission services, financial services, bank services, and health services clinics (IMF, 2021).

On 4 May 2020, the authorities began easing the restrictions by reopening some businesses under a Conditional Movement Control Order (CMCO). Later on 10th June, a Recovery Movement Control Order (RMCO) entered into force, withdrawing the domestic operation and mobility restrictions. These measures successfully contained the pandemic in Malaysia for a short while. Unfortunately, following an election in the State of Sabah in September 2020, new cases spiked, leading to the government reintroducing movement control orders. However, selective MCOs were implemented at this stage, consisting of MCO, Conditional MCO, Enhanced MCO, Targeted Enhanced MCO, and Recovery MCO, as shown in Figure 3. 
FIGURE 1.1.1. New Cases vs Recoveries

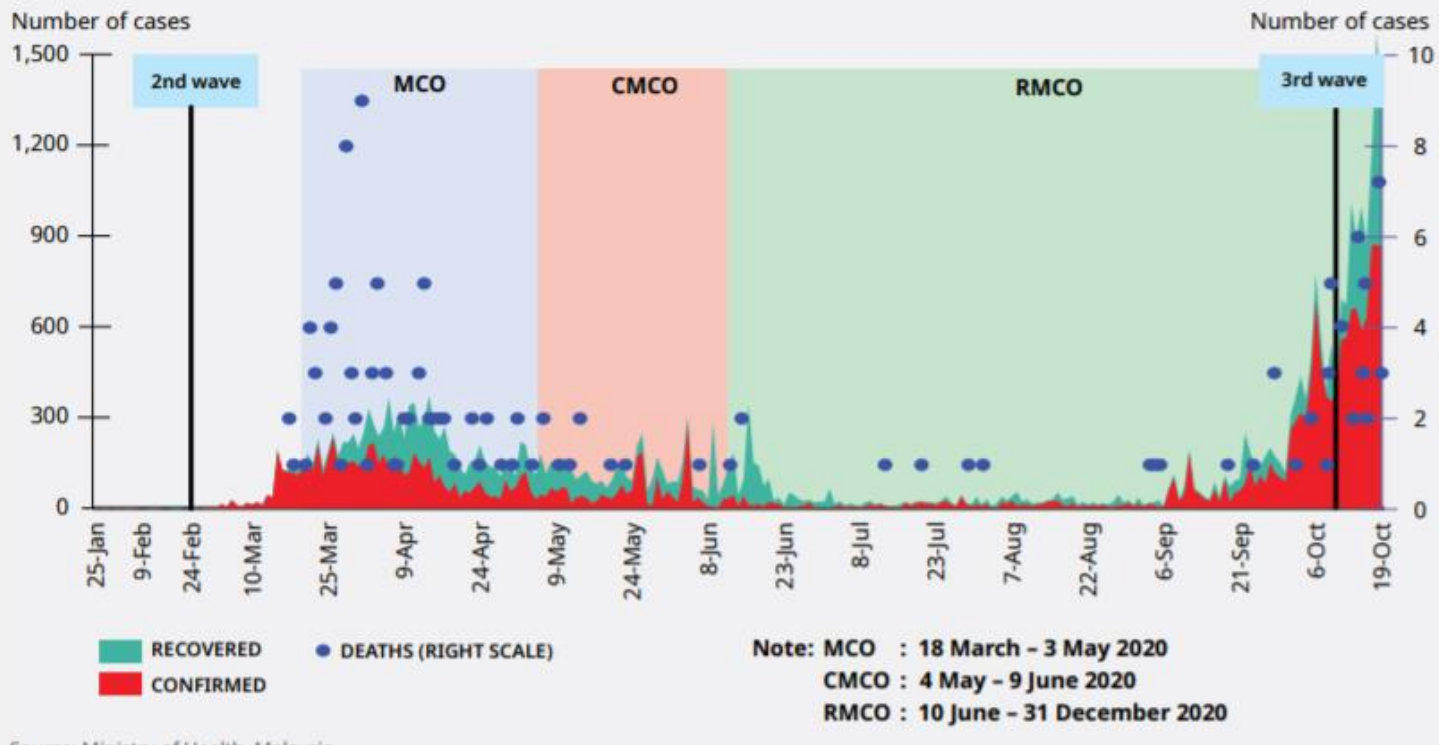

Figure 3

COVID-19 new cases and recoveries

Source: Ministry of Health, Malaysia

\section{Small-Medium Enterprises (SMEs) affected by COVID-19 pandemic}

In China, several SMEs were forced to close for over a month. However, although the approval to reopen, many SMEs cannot resume business, which has caused substantial economic losses and threats to many. Most catering industries in Sichuan have not resumed work in China, and only a few have taken out services; most emerging economies have opened online businesses (Lu et al., 2021). Analysts accurately forecast serious world recessions. Governments also placed the MCO on various industries, required social distancing, and closed the operation of non-essential industries, resulting in critical supply and demand issues for the US economy (Del Rio-Chanona et al., 2020).

The COVID-19 epidemic affected most people's lives, especially the economy, because all governments in other nations, including Indonesia, had social distancing policies. It has impacted the activities of SMEs in Indonesia because they are unable to operate, as usual, resulting in a decrease in demand and revenue. At the same time, because SMEs in Indonesia do not terminate employment, they must continue to pay regular expenses such as salary, rent, instalments, and bank interest. The government has implemented an economic stimulus strategy to sustain the industry's SMEs, including direct cash assistance, preemployment cards, electricity cost deductions, and the Program Keluarga Harapan (Lutfi et al., 2020).

In the United States, 22 million workers have become unemployed within a month, unemployment level more than twice if compared to Austria (Schnetzer et al., 2020). The reduction in market demand and spending could intensify upcoming layoffs and bankruptcies in many impacted industries in 2020. Because of transportation disruptions and labour shortages, SMEs encountered supply-side logistics challenges. On the demand side, SMEs have experienced considerable drops in demand because of lockdown. The magnitude of certain demands and supply shocks may differ depending on whether the company is an 
MANAGEMENT SCIENCES

Vol. 11, No. 3, 2021, E-ISSN: 2225-8329 @ 2021 HRMARS

independent, specialist provider or an SME based on expertise. These complexities are necessary to understand better and develop policies for the short and long term. Due to the almost identical uniform shock lockdowns in major economies between April and June 2020, the immediate effect of the shock should be distinguished from its longer-term impact (Juergensen et al., 2020).

As reported by the World Bank (2020), in Pakistan, GDP growth in 2020 is expected to be 1.3 percentage points lower than in the fiscal year 2019, as national and global economic activity slows substantially in the latter months of the fiscal year. If the COVID-19 epidemic prolongs the situation, the real GDP growth for 2020 may fall by 2.2 per cent. For example, microenterprises, small and medium-sized enterprises in Karachi are also facing huge problems. This is included the textile and apparel industries, agriculture, and the transportation business. Businesses closing and disrupted national supply chains have a huge influence on retail and wholesale, transportation, warehousing, and communications services. Pakistan's currency has been weakened, posing yet another challenge to enterprises. According to a recent World Bank report, Pakistan's exchange rate, which had stayed reasonably constant during the fiscal year 20 from June to February, was depreciated by 7.3 per cent in March (World Bank, 2020). According to Sohail (2018) the Pakistan Labour Force Survey (2017-18), the country's unemployment rate is 5.8 per cent. However, it is expected to increase to 8.1 per cent if the situation continues (Siddiqui, 2020).

In Saudi Arabia, the recession has disproportionately affected SMEs. It has revealed the risk that more than half of SMEs may fail during the next several months due to disrupted supply and demand. Small and medium-sized enterprises (SMEs) can substantially impact home economies and global economic prospects (Nurunnabi, 2020). The impact of the COVID-19 disruption varied depending on the sector in Switzerland. In terms of focusing on a transformation driver and implementing diverse technical solutions, SMEs in these sectors have responded differently to their issues (Gregurec et al., 2021). Switzerland was one of the first and most severely affected countries in Europe by COVID-19. The Federal Council (FC) issued a national state of emergency, closing all stores, restaurants, bars, entertainment establishments, and schools, except for food stores and pharmacies (IMF, 2020).

The imposition of the MCOs has caused some uncertainties faced by the businesses, including the SMEs. As a result, these movement restrictions also endangered the viability of businesses, particularly SMEs. These policies have had major economic implications for countries around the world, not only affecting people's everyday lives (Ozili \& Arun, 2020; McKibbin \& Fernando, 2020; Baldwin \& Weder di Mauro, 2020; Shafi et al., 2020). Most industries such as travel, education, oil, entertainment, financial markets, financial institutions were spilt over (Ozili \& Arun, 2020), market shares have fallen drastically (Baker et al., 2020).

SMEs have faced several unexpected problems, especially operating cash flow, which has led to drastic measures such as cutting off raw material supply, growing the entire staff's payroll, and some compulsory staff layoffs (Che Omar et al., 2020). The majority of CEOs described income decline, reduced consumer demand, a lack of suppliers and raw materials, a shortage of working capital, paying wages and bonuses to workers, handling cashflows, debt payments, and employees' mental wellbeing as the most impacted areas of their company (Winarsih et al., 2020; Gossling et al., 2020). SMEs needs to change their mindset in running a business by using technology transformation. It is believed to continue the sustainability of SMEs; an online business can result in sustainability in their business that can take place now and in the future (Winarsih et al., 2020; Sarkis et al., 2020). 
MANAGEMENT SCIENCES

Vol. 11, No. 3, 2021, E-ISSN: 2225-8329 @ 2021 HRMARS

During the recession, the SMEs in the furniture industry also impacted severely in the financial position and the supply chain interference. Inevitably, the capability to pay salaries, utilities, debt servicing, and other obligations was harmed, though not completely lost. SMEs in the furniture industry largely focus conventionally on the United States, Europe, Japan, and Singapore. Consequently, it is important to examine new potential markets for SMEs to expand their market power using an online distribution channel (Ratnasingam et al., 2020). The fabrics industry has been affected heavily when a lot of SMEs falls into bankruptcy. The SMEs' profitability and cash holdings show their failure and disclosed a large impact from the pandemic COVID-19 (Gourinchas et al., 2020).

Because of the restrictions on movement in the country, the lowest and greatest stock price have had a detrimental influence on the SMEs based on the amount of economic activity and the closing and opening. It shows that monetary policy decisions had a large and negative impact on economic activity and the closing, opening, lowest, and maximum stock prices. The thirty-day control movement policy or total lockdown has significantly influenced the economy by lowering the amount of general economic activity and negatively affecting stock prices (Ozili \& Arun, 2020; Sansa, 2020).

The COVID-19 pandemic uncovered three patterns surrounding the failure of SMEs and failing jobs. The first idea highlighted the situation of SME company owners and the difficulties they encountered as a result of the pandemic. The second idea exposed the companies' comprehensive experiential predicaments. The third and most critical showed very plainly what SME company owners expect from government and financial institutions to support surviving companies and reviving failing businesses. (Al-Fadly, 2020).

In Malaysia, SMEs play a key role in economic development and control the majority of industries. SMEs play an essential role in providing goods and services that directly impact GDP; however, SMEs have also become a key source of job opportunities, exports, and investments or savings (Ibrahim et al., 2016). According to the World Trade Organization, SMEs constitute the backbone of many economies, accounting for 95 per cent of all businesses globally and 60 per cent of employment. To help Malaysian SMEs, particularly micro-enterprises, the government, and Bank Negara Malaysia allocated additional financing totalling RM4.5 billion across five main programmes. The first is to add RM3 billion to the Special Relief Facility (SRF) for SMEs, bringing RM5 billion. In addition, the overall fund's interest rate will be decreased from 3.75 per cent to 3.5 per cent. The second is to boost the total size of all Economic Sector Facility funds by RM1 billion to RM6.8 billion to improve SMEs' access to funding. The third step is to increase the money available under the Micro Credit Scheme from RM500 million to RM700 million for soft loans. The project is open to all micro-entrepreneurs in all business sectors, including child-care centres, taxi and bus drivers, creative industries, and online dealers. The fourth is that SMEs with fewer than four years of company experience can use the Credit Guarantee Malaysia Berhad's BizMula-i and BizWanita-i schemes to obtain financing of up to RM300,000 under the BizMula-i and BizWanita-i schemes (CGC). The fifth is Syarikat Jaminan Pembiayaan Perniagaan (SJPP), giving RM5 billion in guarantees and enhancing coverage from $70 \%$ to $80 \%$ for SMEs who are having difficulty securing loans.

\section{Methodology}

This study utilised a mixed-method approach with data collected from a questionnaire survey and several semi-structured interviews. The data was collected during a period of two months, i.e., from July to August 2020. The questionnaire was divided into three parts. The 
MANAGEMENT SCIENCES

Vol. 11, No. 3, 2021, E-ISSN: 2225-8329 @ 2021 HRMARS

first part of the questionnaire was designed to identify the background of SMEs in Malaysia. The second part of the questionnaire is to identify the impact of SMEs during the Covid 19 crisis. The third part is to identify whether SMEs received the stimulus package and whether they switch to another channel of distribution like an online channel to sustain their business. The questionnaire was administered using Google Forms.

As the data collection was conducted during RMCO conditions, data were collected in two phases. In phase one, most of the SMEs had resumed operation. An online survey was conducted from July 15, 2020, until July 31, 2020. About 300 questionnaires were posted through email, WhatsApp, and telegram. The questionnaires were distributed using personal contacts to the respondent from SMEs throughout Malaysia. However, only 51 completed questionnaires were accepted for further data analysis purposes. The compiled data of responses were analysed and presented graphically.

During phase two, face to face interviews was conducted with 20 SMEs that agreed to be interviewed. The following questions were asked during the interviews: (1) How did COVID19 affect your company? (2) how do you rate the impact on your business, (3) how much has the demand of your product or services been affected, (4) do you have any problem restocking or distributing your product? (5) Does your business face a shortage of workers? (6) Do you implement a retrenchment strategy? (7) Does COVID-19 affect your business financial state, (8) Do you keep contingency funds to finance the company overhead during MCO? (9) Do you switch to digital resources or online channels to support your business operation? (10) Do you take the stimulus package offered by the government? (11) Was it helpful to sustain your business? Each interview lasted between 20 to $30 \mathrm{~min}$, and the conversations were recorded and later transcribed.

\section{Results and Discussion}

\section{The demographic background of the SMEs}

The demographic background of the SMEs is presented in Table 2. Most of the SMEs who responded to the survey came from the sole proprietorship male group representing $31.4 \%$ of the sample. Partnership business owned by both male and female partners represents $31.4 \%$, while sole proprietorship female and partnership male were $19.6 \%$ and $17.6 \%$, respectively. Most of the SMEs business $(47.1 \%)$ is services business, followed by retail business (33.3\%), manufacturing business (15.7\%), and the remainder is in the wholesale and construction business. Most of the SMEs participating in this study (37.3\%) earned an annual turnover of less than RM300,000, while $23.5 \%$ earned up to RM3 million. 
INTERNATIONAL JOURNAL OF ACADEMIC RESEARCH IN ACCOUNTING, FINANCE AND MANAGEMENT SCIENCES

Vol. 11, No. 3, 2021, E-ISSN: 2225-8329 @ 2021 HRMARS

Table 2: Demographic Background of SMEs

\begin{tabular}{|c|c|c|}
\hline Indicator & Item & Proportion \\
\hline \multirow[t]{4}{*}{ Ownership of Business } & Sole Proprietorship - Male & $31.4 \%$ \\
\hline & Partnership - Mix & $31.4 \%$ \\
\hline & Sole Proprietorship - Female & $19.6 \%$ \\
\hline & Partnership - Male & $17.6 \%$ \\
\hline \multirow[t]{5}{*}{ Nature of Business } & Service & $47.1 \%$ \\
\hline & Retail & $33.3 \%$ \\
\hline & Manufacturing & $15.7 \%$ \\
\hline & Construction & $1.95 \%$ \\
\hline & Wholesale & $1.95 \%$ \\
\hline \multirow[t]{5}{*}{ Annual Turnover } & Service and other sectors $-<\mathrm{RM} 300,000$ & $37.3 \%$ \\
\hline & Service and other sectors - RM300,000 to RM 3 & $23.5 \%$ \\
\hline & mil & $15.7 \%$ \\
\hline & $\begin{array}{l}\text { Service and other sectors - RM300,000 to RM } 20 \\
\text { mil }\end{array}$ & $11.8 \%$ \\
\hline & Manufacturing - RM 300,000 to RM 15 mil & \\
\hline
\end{tabular}

Figure 4 shows the number of employees at three levels of management, i.e., top management, middle management, and operational staff.

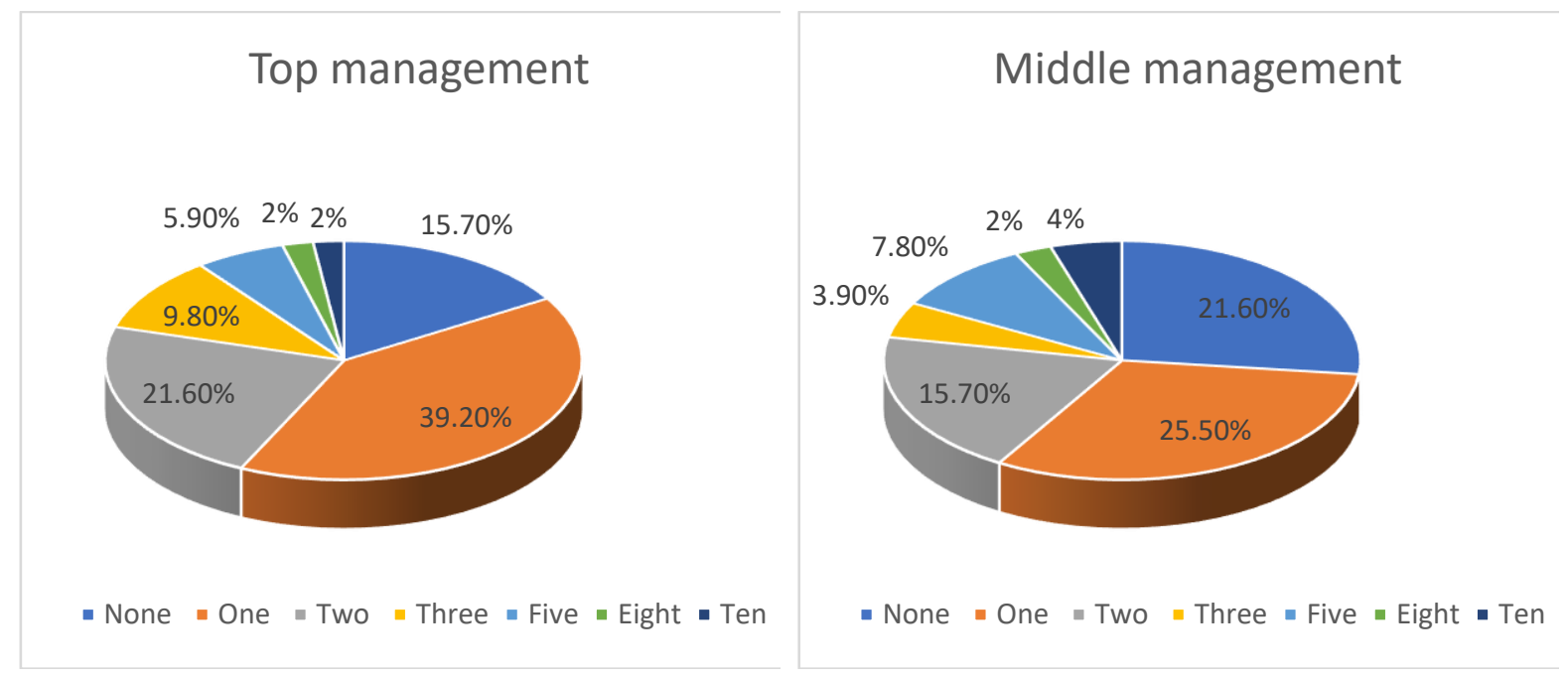




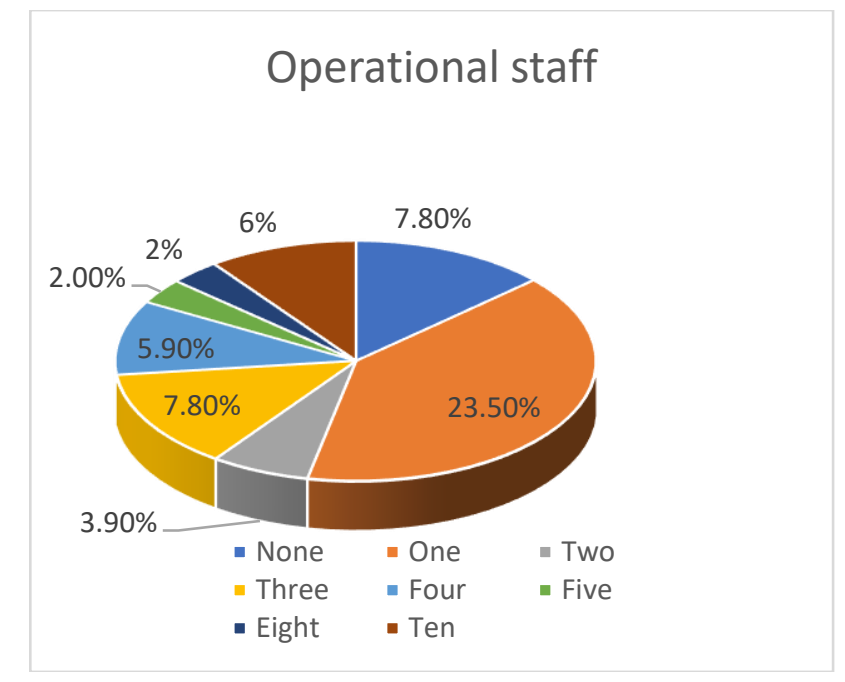

Figure 4

Number of employees in different staff level

As shown in Figure 4, for top management (Chairman/Director/ CEO) position, 39.2\% in the survey have only one top management, $21.6 \%$ have two top management, $9.8 \%$ three top management, $5.9 \%$ have five top management, $2 \%$ have 8 top management, $2 \%$ have top management, and $15.7 \%$ do not have top management. Meanwhile, for the middle management level, consisting of managers and Head of the department, the study found that $25.5 \%$ have only one middle management, $15.7 \%$ have two middle management, $3.9 \%$ have three middle management, $7.8 \%$ have four middle management, $9.8 \%$ have five middle management, $2 \%$ have eight middle management, $3.9 \%$ have ten middle management and $21.6 \%$ do not have middle management. Finally, for the operational staff, the majority of the SMEs only have one operational staff (23.5\%).

\section{COVID-19 Impact on SMEs}

\section{Interruption of Business Operation}

According to the survey results, most respondents (84.3\%) were affected by the COVID-19 issue, while only over $16 \%$ claimed not to be affected (Table 3 ). 
MANAGEMENT SCIENCES

Vol. 11, No. 3, 2021, E-ISSN: 2225-8329 @ 2021 HRMARS

Table 3: Impact of COVID-19 on SMEs interruption of business operation

\begin{tabular}{|l|l|l|l|}
\hline No & Items & The result of the survey & $\%$ \\
\hline 1. & $\begin{array}{l}\text { How did COVID-19 } \\
\text { affect your } \\
\text { company? }\end{array}$ & The company was affected by COVID-19 & $84.3 \%$ \\
\hline 2. & $\begin{array}{l}\text { How do you rate the } \\
\text { impact on the } \\
\text { business? }\end{array}$ & $\begin{array}{l}\text { High impact (put their company out of business) } \\
\text { Medium impact (need to change the way they do } \\
\text { their business) } \\
\text { Low impact (only with some impact, but } \\
\text { confident of sustaining in the business) } \\
\text { None }\end{array}$ & $\begin{array}{l}21.6 \% \\
49 \% \\
27.5 \%\end{array}$ \\
\hline 3. & $\begin{array}{l}\text { Was your business } \\
\text { suspended due to } \\
\text { the movement } \\
\text { control order? }\end{array}$ & $\begin{array}{l}\text { The business was suspended because of the } \\
\text { movement control order }\end{array}$ & $31.4 \%$ \\
\hline 4. & $\begin{array}{l}\text { Does your business } \\
\text { have to change its } \\
\text { hours of operation } \\
\text { due to covID-19? }\end{array}$ & $\begin{array}{l}\text { Hours of operations had to be changed due to } \\
\text { CovID-19 }\end{array}$ & $56.9 \%$ \\
\hline
\end{tabular}

Most of the SMEs in Malaysia rated the impact of the pandemic on their business at medium impact (49\%) where they may need to change the way they operate their business, and there are some SMEs rated as low impact $(27.5 \%)$ which confidently sustained their business during the pandemic. Only $21.6 \%$ of the SMEs rated the impact as high, which expected that the COVID-19 crisis would cease their business. The rate of impact may be different because of the nature of the business, either essential or non-essential category. Under the essential category, the businesses were allowed to remain open, while non-essential businesses were required to close temporarily. The essential category of SMEs includes businesses such as sewage, electricity services, postal services, transportations, drainage, gas and fuel services, gasoline, lubricants, health services like pharmacies and clinics. The pandemic least impacted these essential businesses, and some even managed to earn increased revenue due to the higher demand for their product. For example, food, healthcare, pharmacy, optometrist, delivery service and information technology. In contrast, non-essential businesses were more vulnerable to a COVID-19 crisis, such as the food and beverage industry. It is consistent with prior studies such as Gregurec (2021), Ratten (2020) and Bretas \& Alon (2020).

Interview findings indicated that the rate of impact might also be influenced by the size of the SMEs and their contingency fund to survive. The small SMEs might face a larger impact than the larger size SMEs because of the cash contingency funds held by the company. It is similar to the findings by Al-Hyari, 2020; Humphries et al. (2020) and Bartik et al. (2020), where smaller businesses were found to have less cash on hand to meet their financial needs.

Our survey found that $31.4 \%$ of the respondents had to suspend their businesses because of the movement control order. It has impacted the chance of survival of SMEs during the pandemic. In particular, the chance of survival for firms in service industries such as homestay, travel agents, and beauty centres drops if this crisis continues. A similar predicament was reported by restaurant operators interviewed. Among the three restaurant owners interviewed, one owner commented: 
MANAGEMENT SCIENCES

Vol. 11, No. 3, 2021, E-ISSN: 2225-8329 @ 2021 HRMARS

"I believe that restaurant businesses have a chance of survival if the crisis lasts only in the short-term, but if the crisis lasts longer, we may have a slim chance of survival."

One of the possible reasons for their low chance of survival is the limited operating hours faced by the businesses. $56.9 \%$ of the respondents reported that their hours of operations had to be changed due to COVID-19. As a result, many companies shifted towards a remote working operation to prevent spreading the virus. Additionally, our study found that some SMEs have to change their product and service delivery methods. Some businesses used digital platforms as their main distribution channel during the pandemic, such as those in the food and beverage industry. Previous studies have also reported the digitalisation of businesses during COVID-19 by taking immediate action to switch to online distribution channels (Gregurec, 2021).

\section{Supply Chain Disruption}

During the COVID-19 crisis, our survey showed that the SMEs faced supply chain disruption, which impacted their businesses, as shown in Table 4. From the demand perspective, a large percentage of the businesses (49\%) reported that demand has decreased for most of their products and services. In comparison, 35.3\% experienced a fall in demand for selected items.

Table 4: Impact of COVID-19 on the SME supply chain

\begin{tabular}{|l|l|l|l|}
\hline No & Items & The result of the survey & $\%$ \\
\hline 1. & $\begin{array}{l}\text { How much has the } \\
\text { demand for your } \\
\text { product or services } \\
\text { been affected? }\end{array}$ & $\begin{array}{l}\text { No effect on the demand of the products or } \\
\text { services } \\
\text { Demand has decreased for most of the products } \\
\text { or services } \\
\text { Demand has decreased for selected products or } \\
\text { services } \\
\text { No demand for all the products/services } \\
\text { Demand has increased for selected products or } \\
\text { services }\end{array}$ & $\begin{array}{l}13.7 \% \\
49 \% \\
35.3 \% \\
5.9 \% \\
11.8 \%\end{array}$ \\
\hline 2. & $\begin{array}{l}\text { Do you have any } \\
\text { problem restocking } \\
\text { or distribute your } \\
\text { product? }\end{array}$ & $\begin{array}{l}\text { No access to stock or incoming stock was } \\
\text { interrupted } \\
\text { Cannot distribute their product or deliveries are } \\
\text { interrupted } \\
\text { Have both effects that are no access to stock } \\
\text { and cannot distribute their product } \\
\text { Not applicable }\end{array}$ & $25.5 \%$ \\
\hline
\end{tabular}

However, as shown in Table 4, only a small percentage (13.7\%) reported that the pandemic does not affect the demand for their products and services. Some SMEs reported an increase in demand for selected products or services (11.8\%). It could be due to two possible reasons. Firstly, businesses of essential products and services were allowed to operate as usual. Therefore, there is no interruption in delivering products and services to the customers, leading to no change in demand. Secondly, some of the products experienced an increased demand since these are necessary products to be consumed for health reasons during the pandemic. These include products such as safety masks and sanitisers. Similarly, the increase 
MANAGEMENT SCIENCES

Vol. 11, No. 3, 2021, E-ISSN: 2225-8329 @ 2021 HRMARS

in demand was also expected for clinics and pharmacies to provide swab tests, health supplements, and medication.

A further interview with an optometrist business corroborated the above results. The optometrist commented that:

"The demand for glasses has increased due to Open Distance Learning implemented by the education sector. Mostly, these are school students and teachers who need new glasses because of long hours using the computers. So, our demand increased during this pandemic." Our survey also shows that some SMEs did not demand all their products or services during the COVID-19 crisis. For example, an interviewed construction company owner commented that they had to stop their operation during the COVID-19 fully. It was because of the movement control order (MCO) imposed by the government. Even existing construction projects had to be stopped at the time.

A further impact of COVID-19 on the SMEs was related to the availability of stock from the suppliers. As shown in Table 4, 11.8\% of the respondents had no access to stock and interruption of incoming stock due to the imposition of the MCO. They could not cross between states to get supplies during MCO. Similarly, $21.6 \%$ noted that the MCO restricted their movements to deliver their products to customers.

\section{Shortage of Workforce}

A majority of the SMEs (80.4\%) claims from the survey that they are not facing a shortage of workers. There are several reasons for the shortage of workers. Firstly, workers could not go to work due to the movement control order imposed by the government. Secondly, some workers who tested positive or had direct contact with positive COVID-19 patients had to be quarantined. Some of the employees chose to stay away from the operation of the business because they were afraid of being infected with COVID-19. Furthermore, a small percentage of the workers were absent from work since they cared for their family members. These reasons are depicted in Figure 5.

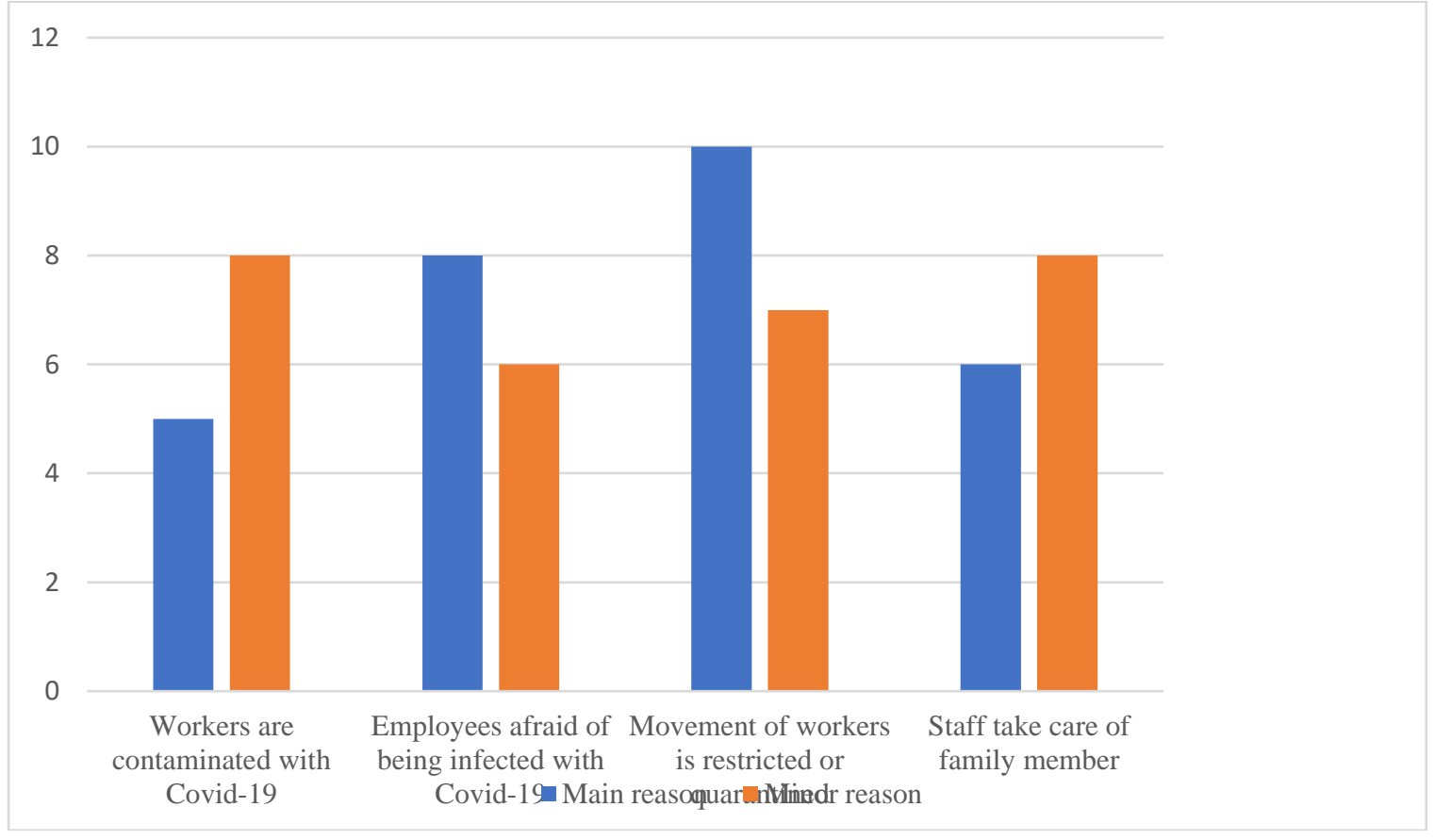

Figure 5

Reasons for the shortage of workers 
MANAGEMENT SCIENCES

Vol. 11, No. 3, 2021, E-ISSN: 2225-8329 @ 2021 HRMARS

When asked about retrenchment strategies in their companies, only around $30 \%$ of the respondents reported that they implemented their retrenchment strategies. It involved the companies laying off workers permanently. It indicates that even though most SMEs in Malaysia were significantly affected by the pandemic (see Table 3), they did not apply a retrenchment strategy at all. It is because some of the businesses were family-owned businesses. Another reason the SMEs maintain their workers is their expectation that the pandemic would not persist for a long time. As such, they decided to retain the workers.

\section{Financial Instability}

Findings of this survey indicated that another impact of COVID-19 on SMEs in Malaysia was the financial instability. The SMEs faced a sharp decline in sales which even forced some businesses to close during the crisis. As shown in Table 5, it was reported that a large proportion of SMEs experiences a negative impact on their financial state. It could be due to the SMEs inability to cover their overheads to finance their business activity.

Table 5: Effect of COVID-19 on the financial state of SMEs

\begin{tabular}{|l|l|l|l|}
\hline No & Question on Impact & The result of the survey & $\%$ \\
\hline 1. & $\begin{array}{l}\text { Does COVID-19 affect your business } \\
\text { financial state? }\end{array}$ & $\begin{array}{l}\text { Affected } \\
\text { Not affected }\end{array}$ & $\begin{array}{l}80.4 \% \\
19.6 \%\end{array}$ \\
\hline 2. & $\begin{array}{l}\text { Do you keep contingency funds to } \\
\text { finance the company overhead during } \\
\text { MCO? }\end{array}$ & $\begin{array}{l}\text { Less than 3 months } \\
\text { 3 to 6 months } \\
\text { More than 6 months }\end{array}$ & $\begin{array}{l}68.6 \% \\
24.87 \% \\
6.53 \%\end{array}$ \\
\hline
\end{tabular}

Only a small percentage of the SMEs (6.53\%) have a contingency fund that can last more than six months from the beginning of the outbreak in Malaysia. A majority of the respondents (68.6\%) reported that they only have a contingency fund to cover their operations for up to 3 months only. This worrying situation could lead the SMEs to permanent closure. It is consistent with the findings of Humphries et al. (2020). Therefore, government intervention, particularly in providing financial support, is essential to sustain the business continuity of these SMEs. Interview findings highlighted those vendors or suppliers of the SMEs did not change the terms of credit during the COVID-19 crisis that could benefit the SMEs. The reason might be due to the Moratorium Scheme offered by various financial institutions, which offered delayed payments to borrowers.

\section{Transformation to Digital Distribution Channel}

The survey findings also reveal that $52.9 \%$ of SMEs switch to digital resources or online channels to sustain their current operations. It is consistent with finding by Lu et al. 2021. Gregurec, 2021; also supported these findings to be true. Some of the SMEs did not use digital resources or online channels, and $17.6 \%$ were at the early stage of exploring to use digital resources or online channels. It may be due to a lack of knowledge in IT and are unwilling to learn the new way of marketing their product or business. 
MANAGEMENT SCIENCES

Vol. 11, No. 3, 2021, E-ISSN: 2225-8329 @ 2021 HRMARS

Table 5: Effect of COVID-19 on transformation to digital distribution channel

\begin{tabular}{|l|l|l|l|}
\hline No & $\begin{array}{l}\text { Question on } \\
\text { Impact }\end{array}$ & The result of the survey & $\%$ \\
\hline 9. & $\begin{array}{l}\text { Do you switch to } \\
\text { digital resources or } \\
\text { online channels to } \\
\text { support your } \\
\text { business } \\
\text { operation? }\end{array}$ & $\begin{array}{l}\text { Yes } \\
\text { Currently exploring }\end{array}$ & $52.9 \%$ \\
\hline
\end{tabular}

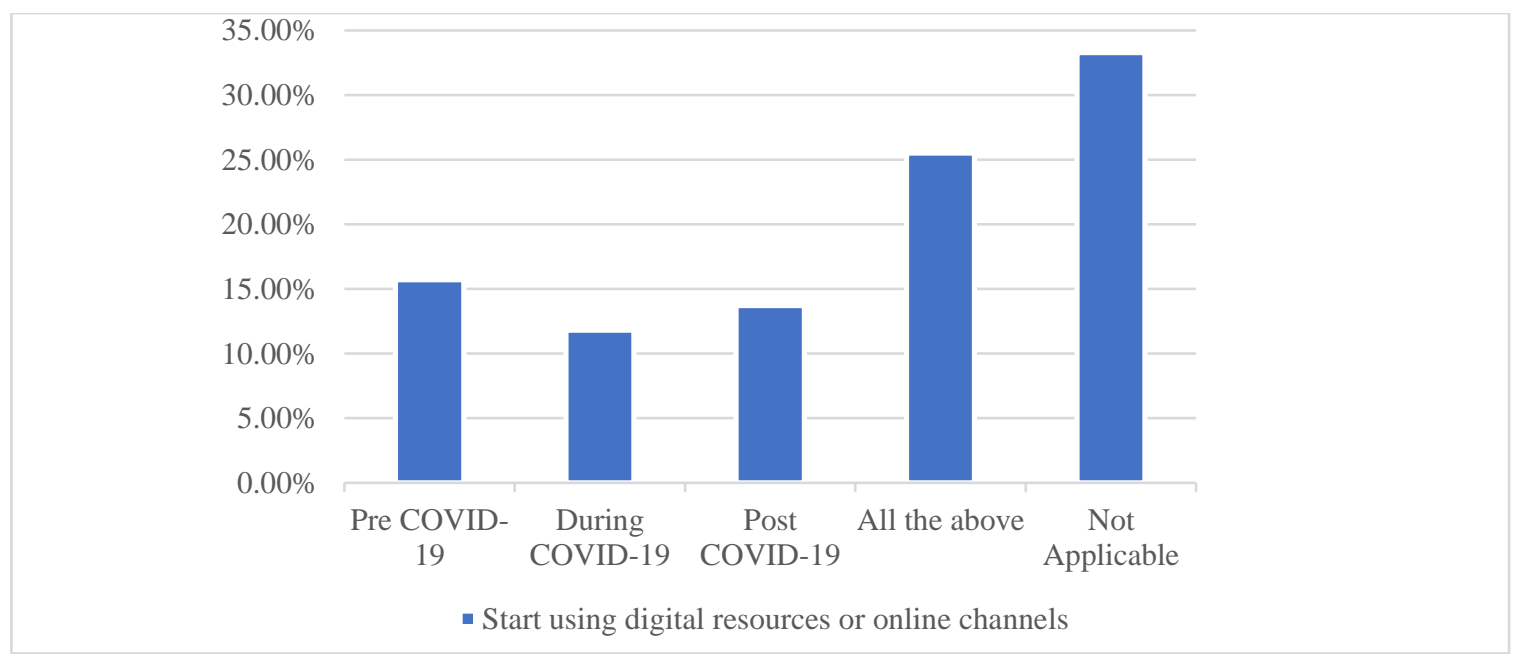

Figure 6

Digital distribution channel

\section{Discussion of Findings}

This paper has identified the various impact of the COVID-19 crisis on SMEs in Malaysia. It was found that the severity of impact differs according to the nature and size of the business. It also depends on whether it is a necessary consumer product or otherwise. However, due to MCO, most of the SMEs' demand and supplies were affected and indirectly, the revenues were affected. The COVID-19 pandemic impacts SMEs both the supply and demand sides. Production chains are disrupted, resulting in components and intermediate goods shortages. Lockdowns and quarantines used to control the outbreak result in more and more serious declines in production. On the production side, employers see a decrease in labour supply when employees are not well or need to handle their children since all the education centres are closed. The daily activities were also limited due to movement restrictions.

On the demand side, SMEs' capacity to survive is negatively impacted by a drastic and abrupt lack in demand and sales, resulting in extreme liquidity shortages. Many SMEs were unable to restart activities due to the reluctance of workers to return to work, strict government lockout conditions, declining consumer demand, and a lack of disease prevention materials. Many SMEs were still experiencing cash flow problems because they had had to budget for different fixed costs while having little or no sales, which might contribute to financial instability and a potential bankruptcy crisis. As a result, most SMEs demanded government policy assistance to resolve existing and anticipated difficulties.

Furthermore, consumers are confronted with income depletion, fear of contagion, and greater volatility, all of which lead to a reduction in savings and consumption. When 
MANAGEMENT SCIENCES

Vol. 11, No. 3, 2021, E-ISSN: 2225-8329 @ 2021 HRMARS

employment is eliminated and firms are unable to pay their employees' wages, the repercussions are amplified. Particularly badly impacted are businesses like as tourism and transportation, which have seen their stock prices and customer confidence drop as a result. Also, SMEs are more susceptible to 'social distancing' than larger companies. The pandemic effects may harm capital markets, causing more loss of interest and credit. These various effects influence both big and small businesses.

While waiting for the government stimulus plan, most SMEs relied on their savings to stay afloat. As a result, companies plan to restart as quickly as possible to rebound sooner. The government is torn between saving the economy and saving Malaysians' livelihoods. Based on our analysis, the government of Malaysia must further continue to support the Malaysian economy by relieving cash flow pressures to assist the SMEs to survive, like financing facilities for SMEs until they can survive independently. The earlier the business can be reopened, the fastest to rebuilt of the SMEs can be done.

The Malaysian Strategic Programme to Motivate the Population and Economy, or PEMERKASA, costing RM20 billion, was launched on March 17, 2021, together with a fiscal intervention of RM11 billion by the government to help the recovery phase continue indefinitely. The top priorities of PEMERKASA are to prevent the spread of COVID-19, accelerate economic growth, increase national prosperity, maintain a regional and group inclusion policy, and change the economy. Among the measures listed in PEMERKASA is an increase in the budget for the immunisation programme from RM3 billion to RM5 billion to move the community immunisation deadline from the first quarter of 2022 to December 2021. The Prime Minister also indicated that the government was committed to revitalising the afflicted economic sectors by launching construction programmes, salary subsidies, tax exemptions, and micro-credit financing facilities right now.

According to the then Prime Minister of Malaysia, PEMERKASA would focus on 20 strategic initiatives to stimulate economic development, promote the industry, and continue targeted assistance to citizens and affected sectors. It is in line with Malaysia's Comprehensive Economic Recovery Plan's also known as the "6R Strategy". The 6R Strategy consists of six components which are: (1) Resolve; (2) Resilience; (3) Restart; (4) Recovery; (5) Revitalise and (6) Reform. Currently, Malaysia is in the fifth stage, which is to revitalise or energise the economy. Apart from that, micro-credit facilities would be made available, including an RM300 million fund with a loan maximum of up to RM50,000 and an interest rate of 3.0 per cent, down from 3.5 per cent. Besides the PEMERKASA program, TEKUN Nasional is also enhanced as additional financial assistance specifically targeted to SMEs. TEKUN Nasional will introduce the TEKUN POS-preneur initiative in which applicants would make money through distribution contracts. Furthermore, the Malaysia SME Corporation would donate RM50 million to assist local small and medium enterprises (SMEs) in securing loans of up to RM250,000 at interest rates as low as 3.0 per cent. Several tax cuts and delayed income tax instalment payments were also proposed to revitalise the travel and retail markets.

\section{Conclusions}

In conclusion, this study has revealed the impact of COVID-19 on SMEs in various ways. How these SMEs adapt to the pandemic to survive, and how government assistance helps SMEs survive during the crises. This study reveals, most SMEs are transforming into digital distribution channels to survive in the industry. The SME owner or manager becomes more inventive in their marketing plan. The aggressive tactics, such as adopting the new order system and making deliveries, resulted in more sales to certain SMEs than previously. 
MANAGEMENT SCIENCES

Vol. 11, No. 3, 2021, E-ISSN: 2225-8329 @ 2021 HRMARS

Furthermore, this study offered concrete evidence of the importance of government assistance for the survival of SMEs during times of crisis. As a result, the findings of this study have substantial implications for governments, which should adopt policies to provide additional stimulus packages for SMEs, such as funding, advisory services, and training. Aside from that, governments should encourage non-governmental organisations (NGOs) to give financial or non-financial assistance to SMEs in the form of consultations, training, advice, counselling, and psychological support to assist them in coping with the challenges caused by COVID-19. Additionally, since the COVID-19 has greatly affected SMEs' financial position, governments encouraged financial institutions to be more flexible in their financing policies, such as rescheduling their loan repayment and providing low-interest loans (Adam \& Alarifi, 2021). Thus, this study contributed to the literature by stating that support from various parties will help SMEs survive in the industry during a crisis. The present study proposes that SMEs should learn from the crisis and develop new ideas and strategies to ensure their sustainability in the future.

\section{References}

Adam, N. A., \& Alarifi, G. (2021). Innovation practices for survival of small and medium enterprises (SMEs) in the COVID-19 times: the role of external support. Journal of innovation and entrepreneurship, 10(1), 1-22.

Akanni, L. O., \& Gabriel, S. C. (2020). The implication of Covid-19 pandemic on the Nigerian Economy. Available at cseaafrica. org/the-implication-ofcovid19-on-the-nigerianeconomy/on July, 20, 2020.

Al-Fadly, A. (2020). Impact of COVID-19 on SMEs and employment. Entrepreneurship and Sustainability Issues, 8(2), 629.

Al-Hyari, K. (2020). Initial empirical evidence on how Jordanian manufacturing SMEs cope with the covid-19 pandemic. Academy of Strategic Management Journal, 19, 1-12.

Bank, W. (2020). East Asia and Pacific in the Time of COVID-19. World Bank East Asia and Pacific Economic update, 234.

Bretas, V. P. G., \& Alon, I. (2020). The impact of COVID-19 on franchising in emerging markets: An example from Brazil. Global Business and Organizational Excellence, 39(6), 6-16.

Bartik, A. W., Bertrand, M., Cullen, Z., Glaeser, E. L., Luca, M., \& Stanton, C. (2020). The impact of COVID-19 on small business outcomes and expectations. Proceedings of the National Academy of Sciences, 117(30), 17656-17666.

Humphries, J. E., Neilson, C., \& Ulyssea, G. (2020). The evolving impacts of COVID-19 on small businesses since the CARES Act.

Baker, S. R., Bloom, N., Davis, S. J., Kost, K., Sammon, M., \& Viratyosin, T. (2020). The unprecedented stock market reaction to COVID-19. The review of asset pricing studies, 10(4), 742-758.

Baldwin, R., \& Weder di Mauro, B. (2020). Economics in the Time of COVID-19. CEPR press.

Bedford, J., Enria, D., Giesecke, J., Heymann, D. L., Ihekweazu, C., Kobinger, G., ... \& Wieler, L. H. (2020). COVID-19: towards controlling of a pandemic. The lancet, 395(10229), 1015-1018.

Buffington, C., Dennis, C., Dinlersoz, E., Foster, L., \& Klimek, S. (2020). Measuring the effect of covid-19 on us small businesses: The small business pulse survey (No. 20-16).

Carlos, W. G., Dela Cruz, C. S., Cao, B., Pasnick, S., \& Jamil, S. (2020). Novel Wuhan (2019nCoV) Coronavirus. Am J Respir Crit Care Med, P7-P8. 
MANAGEMENT SCIENCES

Vol. 11, No. 3, 2021, E-ISSN: 2225-8329 ๔ 2021 HRMARS

Omar, C. A. R., Ishak, S., \& Jusoh, M. A. (2020). The impact of COVID-19 movement control order on SMEs' businesses and survival strategies. Malaysian Journal of Society and Space, 16(2). https://doi.org/10.17576/geo-2020-1602-11

Del Rio-Chanona, R. M., Mealy, P., Pichler, A., Lafond, F., \& Farmer, J. D. (2020). Supply and demand shocks in the COVID-19 pandemic: An industry and occupation perspective. Oxford Review of Economic Policy, 36(Supplement_1), S94S137. https://doi.org/10.1093/oxrep/graa033

Djalante, R., Shaw, R., \& DeWit, A. (2020). Building resilience against biological hazards and pandemics: COVID-19 and its implications for the Sendai Framework. Progress in Disaster Science, 6, 100080.

Gössling, S., Scott, D., \& Hall, C. M. (2020). Pandemics, tourism and global change: A rapid assessment of COVID-19. Journal of Sustainable Tourism, 29(1), 1-20. https://doi.org/10.1080/09669582.2020.1758708

Gourinchas, P., Kalemli-Özcan, Ș., Penciakova, V., \& Sander, N. (2020). COVID-19 and SME failures. https://doi.org/10.3386/w27877

Gregurec, I., Tomičić Furjan, M., \& Tomičić-Pupek, K. (2021). The impact of COVID-19 on sustainable business models in SMEs. Sustainability, 13(3), 1098.

International Monetary Fund IMF. (2020) Word Economic Outlook, April 2020: The great lockdown. https://www.imf.org/en/Publications/WEO/Issues/2020/04/14/weo-april2020

International Monetary Fund. (2021) Policy Responses to Covid 19. https://www.imf.org/en/Topics/imf-and-covid19/Policy-Responses-to-COVID-19\#M

Ibrahim, Z., Abdullah, F., \& Ismail, A. (2016). International business competence and small and medium enterprises. Procedia - Social and Behavioral Sciences, 224, 393-400. https://doi.org/10.1016/j.sbspro.2016.05.402

Juergensen, J., Guimón, J., \& Narula, R. (2020). European SMEs amidst the COVID-19 crisis: Assessing impact and policy responses. Journal of Industrial and Business Economics, 47(3), 499-510. https://doi.org/10.1007/s40812-020-00169-4

Kokudo, N., \& Sugiyama, H. (2020). Call for international cooperation and collaboration to effectively tackle the COVID-19 pandemic. Global Health \& Medicine, 2(2), 60-62. https://doi.org/10.35772/ghm.2020.01019

Kupferschmidt, K., \& Cohen, J. (2020). Can China's COVID-19 strategy work elsewhere? Science, 367(6482), 1061-1062. https://doi.org/10.1126/science.367.6482.1061

Li, Q., Guan, X., Wu, P., Wang, X., Zhou, L., Tong, Y., ... \& Feng, Z. (2020). Early transmission dynamics in Wuhan, China, of novel coronavirus-infected pneumonia. New England journal of medicine.

Lu, L., Peng, J., Wu, J., \& Lu, Y. (2021). Perceived impact of the Covid-19 crisis on SMEs in different industry sectors: Evidence from Sichuan, China. International Journal of Disaster Risk Reduction, 55, 102085. https://doi.org/10.1016/j.ijdrr.2021.102085

Lutfi, M., Buntuang, P. C. D., Kornelius, Y., \& Hasanuddin, B. (2020). The impact of social distancing policy on small and medium-sized enterprises (SMEs) in Indonesia. Problems and Perspectives in Management, 18(3), 492.

https://doi.org/10.21511/ppm.18(3).2020.40

McKibbin, W., \& Fernando, R. (2020). The economic impact of COVID-19. Economics in the Time of COVID-19, 45(10.1162).

M Schnetzer, D., Tamesberger, S. T.(2020), Mitigating mass layoffs in the COVID-19 crisis: Austrian short-time work as international role model, VoxEU. org, 2020. 
MANAGEMENT SCIENCES

Vol. 11, No. 3, 2021, E-ISSN: 2225-8329 ๔ 2021 HRMARS

McKinsey (2020) COVID-19: briefing materials.

https://www.mckinsey.com/ /media/mckinsey/business\%2520functions/risk/our\%2 520insights/covid\%252019\%2520implications\%2520for\%2520business/covid\%25201 9\%2520march\%252025/covid-19-facts-and-insights-march-25-v3.ashx

Nurunnabi, M. (2020). Recovery planning and resilience of SMEs during the COVID-19: experience from Saudi Arabia. Journal of Accounting \& Organizational Change.

Ozili, P. K., \& Arun, T. (2020). Spillover of COVID-19: Impact on the global economy. SSRN Electronic Journal. https://doi.org/10.2139/ssrn.3562570

Ratnasingam, J., Khoo, A., Jegathesan, N., Chee Wei, L., Ab Latib, H., Thanasegaran, G., Liat, C. L., Yan, Yi, L., Othman, K., \& Amir, M. A. (2020). How are small and medium enterprises in Malaysia's furniture industry coping with COVID-19 pandemic? Early evidences from a survey and recommendations for policymakers. BioResources, 15(3), 5951-5964. https://doi.org/10.15376/biores.15.3.5951-5964

Ratten, V. (2020). Coronavirus and international business: An entrepreneurial ecosystem perspective. Thunderbird International Business Review, 62(5), 629-634.

Riou, J., \& Althaus, C. L. (2020). Pattern of early human-to-human transmission of Wuhan 2019 novel coronavirus (2019-nCoV), December 2019 to January 2020. Eurosurveillance, 25(4), 2000058.

Estrada, R. M. A., Park, D., \& Lee, M. (2020). The evaluation of the final impact of Wuhan COVID-19 on trade, tourism, transport, and electricity consumption of China. Tourism, Transport, and Electricity Consumption of China (March 9, 2020).

Sansa, N. A. (2020). The Impact of the COVID-19 on the Financial Markets: Evidence from China and USA. Electronic Research Journal of Social Sciences and Humanities, 2.

Sarkis, J., Cohen, M. J., Dewick, P., \& Schröder, P. (2020). A brave new world: Lessons from the COVID-19 pandemic for transitioning to sustainable supply and production. Resources, Conservation, and Recycling, 159, 104894.

Shafi, M., Liu, J., \& Ren, W. (2020). Impact of COVID-19 pandemic on micro, small, and medium-sized enterprises operating in Pakistan. Research in Globalization, 2, 100018. https://doi.org/10.1016/j.resglo.2020.100018

Siddiqui, S. (2020). COVID-19 lockdown to leave people jobless, businesses closed in Pakistan. The Express Tribune.

Smith, J. A., \& Judd, J. (2020). COVID-19: vulnerability and the power of privilege in a pandemic. Health Promotion Journal of Australia, 31(2), 158.

Sneader, K., \& Singhal, S. (2020). Beyond coronavirus: The path to the next normal. McKinsey \& Company, 5.

Sneader, K., \& Singhal, S. (2020). The future is not what it used to be: Thoughts on the shape of the next normal. McKinsey \& Company, 4.

Sohail, S. (2018). Pakistan employment trends 2018. http://refhub.elsevier.com/S2590051X(20)30007-1/rf0270

Tahir, H. M., Razak, N. A., Rentah, F. (2018) The Contributions Of Small and Medium Enterprises (SME's) On Malaysian Economic Growth: A Sectoral Analysis. In: Lokman A., Yamanaka T., Lévy P., Chen K., Koyama S. (eds) Proceedings of the 7th International Conference on Kansei Engineering and Emotion Research 2018. KEER 2018. Advances in Intelligent Systems and Computing, vol 739. Springer, Singapore. https://doi.org/10.1007/978-981-10-8612-0_73

Tashiro, A., \& Shaw, R. (2020). COVID-19 pandemic response in Japan: What is behind the initial flattening of the curve?. Sustainability, 12(13), 5250. 
Ting, R. (2020). First coronavirus cases in Malaysia: 3 Chinese nationals confirmed infected, quarantined in Sungai Buloh hospital. Borneo Post Online. https://www.theborneopost.com/2020/01/25/first-coronavirus-cases-inmalaysia-3-chinese-nationals-confirmed-infected-quarantined-in-sungai-bulohhospital/

Wang, C., Horby, P. W., Hayden, F. G., \& Gao, G. F. (2020). A novel coronavirus outbreak of global health concern. The lancet, 395(10223), 470-473.

WHO. Report of the WHO-China Joint Mission on Coronavirus Disease 2019 (COVID-19). (2020). https://www.who.int/docs/ default-source/coronaviruse/who-china-jointmission-on-covid-19- final-report.pdf (accessed March 7, 2020)

Winarsih, Indriastuti, M., Fuad, K. (2021) Impact of Covid-19 on Digital Transformation and Sustainability in Small and Medium Enterprises (SMEs): A Conceptual Framework. In: Barolli L., Poniszewska-Maranda A., Enokido T. (eds) Complex, Intelligent and Software Intensive Systems. CISIS 2020. Advances in Intelligent Systems and Computing, vol 1194. Springer, Cham. https://doi.org/10.1007/978-3030-50454-0_48

Zu, Z. Y., Jiang, M. D., Xu, P. P., Chen, W., Ni, Q. Q., Lu, G. M., \& Zhang, L. J. (2020). Coronavirus disease 2019 (COVID-19): a perspective from China. Radiology, 296(2), E15-E25. 